УДК 159.942

DOI https://doi.org/10.32689/maup.psych.2021.3.18

\title{
Яна РАСВСЬКА
}

доктор психологічних наук, доцент, професор кафедри психології, Інститут підготовки кадрів Державної служби зайнятості України, вул. Нововокзальна, 17, Київ, Україна, 03038

ORCID: 0000-0003-3802-2304

\section{Ольга СОЛЯКОВА}

аспірантка кафедри психології, Інститут підготовки кадрів Державної служби зайнятості України, вул. Нововокзальна, 17, Київ, Україна, 03038

ORCID: 0000-0002-9696-7018

\section{Yana RAIEVSKA}

Doctor of Psychology, Associate Professor, Professor, Department of Psychology, Ukrainian State Employment Service Training Institute, 17 Novovokzalna Str., Kyiv, Ukraine, 03038

ORCID: 0000-0003-3802-2304

\section{Olha SOLIAKOVA}

Postgraduate of the Department of Psychology, Ukrainian State Employment Service Training Institute, 17 Novovokzalna Str., Kyiv, Ukraine, 03038

ORCID: 0000-0002-9696-7018

\section{РОЗВИТОК ЕМОЦІЙНОЇ КОМПЕТЕНТНОСТІ ОСОБИСТОСТІ: ТЕОРЕТИЧНИЙ ДИСКУРС}

\section{DEVELOPMENT OF EMOTIONAL PERSONALITY COMPETENCE: THEORETICAL DISCOURSE}

У статті здійснено спробу розкрити сутність феномена емоиійної компетентності особистості, а також проаналізувати типи компетентностей особистості та на їх основі визначити компоненти та маркери рівня розвитку емоиійної компетентності. Продемонстровано різноманітність підходів до визначення компетентності.

Проаналізовано конструкт емочійної компетентності, щзо складається з чотирьох базових компонентів - рефлексї, саморегулячії, регулячії взаємин та емпатії, які утворюють чотири функиіональні блоки - поведінковий, когнітивний, інтраперсональний та інтерперсональний.

Визначено, що близькими до поняття «емочійна компетентність» $є$ «особистісна компетентність», «сочіальна компетентність», «сочіально-психологічна компетентність», "рольова компетентність» та «комунікативна компетентність».

Поняття «емоційна компетентність» визначено як готовність $і$ здатність людини гнучко управляти власними емоційними реакціями та реакціями інших людей, адекватно до ситуацій і умов, щзо змінюються, та використовувати изі здатності для досягнення важливих иүілей як у житті загалом, так $і$ у професійній діяльності зокрема.

У структурі емоційної компетентності особистості виокремлено компоненти (афективно-когнітивний, ціннісно-мотиваційний, поведінково-діяльнісний) та рівні (високий, достатній, середній, низький).

Подано особистісну характеристику емочійно компетентної людини, якій властиві врівноваженість, сумлінність, доброзичливість, комунікабельність, відкритість; людина, яка легко уживається з іншими й перебуває у злагоді із собою, здатна контролювати власні емоції, адекватно оцінюючи їх природу й причину.

Констатовано, ще наявні наукові здобутки є недостатніми для чіткого розуміння феномена емоційної компетентності та основи вивчення психологічних підходів до розуміння емоційної компетентності, обтрунтовано визначення иъього феномена як методологічного фундаменту конструювання та реалізації розвивальних програм. Перспективою дослідження визначено з 'ясування функиіональних конструктів розвитку емоційної компетентності особистості.

Ключові слова: особистість, типи компетентностей, емоційна компетентність, емоиійний інтелект, компоненти емоційної компетентності, рівні розвитку емоційної компетентності.

The article attempts to reveal the essence of the phenomenon of emotional competence of the individual, as well as to analyze the types of personality competencies and on their basis to determine the components and markers of the level of emotional competence. A variety of approaches to determining competence have been demonstrated. 
The construct of emotional competence is analyzed, which consists of four basic components - reflection, selfregulation, regulation of relationships, and empathy, which form four functional blocks - behavioral, cognitive, intrapersonal and interpersonal.

It is determined that close to the concept of "emotional competence" are "personal competence", "social competence", "socio-psychological competence", "role competence" and "communicative competence".

The concept of "emotional competence" is defined as the willingness and ability to flexibly manage their own emotional reactions and the reactions of others, appropriate to changing situations and conditions and use these abilities to achieve important goals in life in general and professional activities in particular.

In the structure of emotional competence of the individual components (affective-cognitive, value-motivational, behavioral-activity) and levels (high, sufficient, average, low) are distinguished.

The personal characteristics of an emotionally competent person, which is characterized by balance, honesty, friendliness, sociability, openness; a person who easily gets along with others and is in harmony with himself, is able to control their own emotions, adequately assessing their nature and cause.

It is stated that the existing scientific achievements are insufficient for a clear understanding of the phenomenon of emotional competence and the basis for studying psychological approaches to understanding emotional competence, the definition of this phenomenon as a methodological foundation for designing and implementing development programs. The perspective of the research is to find out the functional constructs of the development of emotional competence of the individual.

Key words: personality, types of competencies, emotional competence, emotional intelligence, components of emotional competence, levels of emotional competence development.

Постановка проблеми. Проблема емоційної культури особистості залишається важливою протягом усієї історії людства. Надмірна емоційна експресивність і безконтрольність емоцій, що виявляються, впливає на якість міжособистісних стосунків особистості, а 3 іншого боку, надмірна їх стриманість призводить до того, що людина сприймається як холодна, байдужа, зарозуміла, що викликає в оточуючих подив або неприязнь.

В умовах сьогодення велика увага приділяється емоційному інтелекту й емоційній компетентності особистості як головній умові ефективної міжособистісної взаємодії. Розвинений емоційний інтелект може бути показником психологічного благополуччя особистості та успішності иї професійної діяльності.

У вітчизняній психології наголошується, що емоційний інтелект має найбільше значення під час роботи у сферах діяльності, які тісно пов'язані зі спілкуванням та взаємодією 3 іншими людьми у суб'єкт-суб'єктних відносинах, та виступає як головний регулятор життєвої стабільності та професійної діяльності особистості. Емоційна компетентність особистості як сукупність набутих знань, сформованих умінь і навичок, збагачуе іiі досвід і дозволяє успішно здійснювати професійну діяльність у сучасних умовах [2].

Аналіз останніх досліджень і публікацій. Вченими-психологами емоційний інтелект визначається як здатність людини розуміти власне ставлення до зовнішнього світу та керувати емоційною сферою на основі інтелектуального аналізу і синтезу (Д. Карузо, Дж. Майєр, П. Саловей); як сукупність ментальних здібностей до розуміння власних емоцій і емоцій інших людей, а також до керування емоційною сферою (І. Андрєєва). У сучасних дослідженнях встановлено пози- тивний вплив емоцій на мнемонічні процеси (Т. Сисоєва), на структуру інтелекту (Л. Засєкіна), на ефективність інтелектуальної та пізнавальної діяльності (О. Божок, О. Тихомиров, О. Чебикін), на успішність професійної діяльності (О. Саннікова).

Дослідження емоційного інтелекту у зарубіжній психології було започатковано в роботах Е. Торндайка, який проводив дослідження щодо вивчення здатності до розпізнавання емоцій, і Г. Гарднера, який розробляв теорію множинності форм інтелекту, та виокремлено типи інтелекту, пов'язані з емоційно-інтелектуальними здібностями (міжособистісний i внутрішньоособистісний) [13].

Дж. Майєр та П. Саловей сконцентрували увагу на відмінностях, які відрізняють конструкт емоційного інтелекту від персональних факторів, й охарактеризували зміст емоційного інтелекту як сукупність розумових здібностей [14].

Р. Бар-Он, Д. Гоулмен, Д. Люсіна трактують емоційний інтелект як специфічне психічне утворення 3 одночасною репрезентованістю когнітивних i особистісних характеристик, зокрема модель Р. Бар-Она включає адаптаційні здібності, стратегії подолання стресових ситуацій [11]; модель Д. Гоулмена - самосвідомість і самомотивацію; Д. Люсіною визначено двокомпонентну модель емоційного інтелекту, зокрема внутрішньоособистісний емоційний інтелект (розуміння та управління власними емоціями, контроль експресії) та міжособистісний емоційний інтелект (розуміння та управління емоційними станами інших) [10].

О. Саннікова виділила відмінні ознаки актуальних (ситуативних) емоцій та стійких (позаситуативних) емоційних переживань, емоційно-диференціальні відмінності щодо особливостей поведінки у стресових ситу- 
аціях. Е. Носенко виділено концепти щодо операціоналізації поняття емоційного інтелекту, започатковано вивчення адаптивних та стресозахисних властивостей емоційного інтелекту, розвитку емоційного інтелекту [5].

О. Власовою визначено емоційний інтелект як емоційно-інтелектуальну здатність, що полягає в емоційній сенситивності, обізнаності та здатності управляти емоціями, які дозволяють людині контролювати відчуття психічного здоров'я, душевної гармонії [3].

Мета статті - проаналізувати феномен емоційної компетентності особистості в аспектах окреслення компонентів такого конструкту та іiї розвитку.

Виклад основного матеріалу. Компетентність розглядаємо як якість особистості, її певне надбання, що грунтується на знаннях, досвіді, моральних засадах і проявляється в критичний момент за рахунок вміння знаходити зв'язок між ситуацією та знаннями, у прийнятті адекватних рішень нагальної проблеми.

У сучасній науці поняття «компетентність» розуміють як:

- якість особистості або сукупність якостей, мінімальний досвід діяльності у заданій сфері (I. Андрєєва) [1];

- вміння мобілізувати в конкретній ситуації отримані знання та досвід з урахуванням зовнішніх обставин; деяку загальну здатність людини, що базується на їі знаннях, досвіді, цінностях і здібностях та яка не зводиться ні до конкретних знань, ні до навичок, а проявляється як можливість встановлення зв'язку між знанням та ситуацією (І. Матійків) [8];

- рівень готовності застосування знань, умінь, навичок у різних ситуаціях (В. Зарицька) [6];

- поєднання відповідних знань і здібностей, що дають підставу обгрунтовано судити про цю сферу й ефективно діяти в ній; володіння людиною відповідною компетенцією, що включає особисте ставлення до неї та предмета діяльності (С. Деревянко) [4].

На думку Я. Раєвської, компетентність більш широкепоняття, яке характеризує івизначає рівень професіоналізму особистості, а іiі досягнення відбувається через здобуття необхідних компетенцій, що становлять мету професійної підготовки фахівця [9].

I. Зимня виділяе 3 основні групи компетентностей:

- компетентності, що належать до особистості як до суб'єкта життєдіяльності;

- компетентності, що належать до взаємодії людини з іншими;

- компетентності, що належать до діяльності людини та проявляються в усіх іiі типах та формах [7].
Визначаючи характеристики компетентності, I. Зимня розрізнює такі їх аспекти, як: мотиваційний (здатність до прояву компетентності), когнітивний (володіння знанням змісту компетентності), поведінковий (досвід прояву компетентності в різноманітних стандартних та нестандартних ситуаціях), ціннісно-смисловий (відношення до змісту компетентності та об’єкта її застосування), емоційний (емоційно-вольова регуляція процесу та результату прояву компетентності) [7].

У такій інтерпретації поняття компетентності, ii характеристики розглядаються як загальні орієнтовні критерії оцінки їі змісту, що свідчить про складність іiі виміру та оцінки.

Емоційну компетентність розглядаємо як здатність усвідомлювати емоції, як свої, так і оточуючих. Люди 3 високим рівнем емоційного інтелекту мають навички, які дозволяють їм впевненіше почуватися у суспільстві та досягати значущих результатів.

Конструкт емоційної компетентності складається 3 чотирьох базових компонентів рефлексії, саморегуляції, регуляції взаємин та емпатії, які утворюють чотири функціональні блоки - поведінковий, когнітивний, інтраперсональний та інтерперсональний [12].

Коротко охарактеризуємо базові компоненти емоційної компетентності та іiі значення у процесі міжособистісної взаємодії.

1. Рефлексія. У загальному вигляді до рефлексії належать здібності людини визначати, яку саме емоцію вона відчуває в певний момент, за фізичним станом та внутрішнім діалогом; співвідносити цю емоцію $з$ іiі назвою; визначати, 3 яких базових емоцій складається випробуваний складник, усвідомлювати зміну інтенсивності емоції та переходи від однієї емоції до іншої. Слід зазначити, що розуміння емоцій тісно пов'язане 3 можливостями висловлювання.

2. Під саморегуляцією розуміється вміння визначати джерело та причину виникнення емоції, иї призначення та можливі наслідки розвитку, ступінь іiі корисності у конкретній ситуації; відповідно до цього за необхідності знайти спосіб регуляції емоції (зміни ступеня iii інтенсивності або заміни на іншу емоцію), керуючи диханням, станом тіла, використовуючи вербальні та невербальні способи управління емоціями та управління внутрішнім діалогом. До цього ж уміння належить здатність викликати у себе емоцію, необхідну у конкретній ситуації.

Слід зазначити, що адекватна емоційна експресія $\epsilon$ важливим чинником підтримки фізичного та психічного здоров'я. Стримування емоцій сприяє виникненню різноманіт- 
них захворювань. Водночас безконтрольність емоційної експресії ускладнює міжособистісне спілкування.

3. Регуляція взаємин передбачає вміння визначати можливу причину виникнення емоції в іншої людини та прогнозувати наслідки iii прояву; змінювати емоційний стан іншої людини (інтенсивності емоцій, переходу на іншу емоцію) за допомогою вербальних та невербальних засобів; здатність викликати необхідну емоцію в інших.

4. Емпатія є базовим складником емоційної компетентності. Традиційно такий феномен сприймається як розуміння емоційного стану, співпереживання; це емоційний відгук людини на переживання інших людей та проявляється ідентично до того, як переживає конкретна людина.

У сучасній психології розрізняють кілька видів емпатії: емоційну, що заснована на механізмах проєкції та наслідування реакцій іншої людини; когнітивну, що базується на інтелектуальних процесах (порівняння, аналогія тощо), і предикативну, що виявляється як здатність людини передбачати афективні реакції іншої особистості в конкретних ситуаціях.

Узагальнюючи вищесказане, можна відзначити, що особистість 3 високим рівнем розвитку емоційної компетентності має виражені здібності до розуміння власних емоцій та емоцій інших людей, до управління емоційною сферою, що зумовлює більш високу адаптивність та ефективність у спілкуванні та професійній діяльності.

Близькими до поняття «емоційна компетентність» $\epsilon$ «особистісна компетентність, «соціальна компетентність», «соціально-психологічна компетентність», «рольова компетентність»та«комунікативнакомпетентність».

Особистісна компетентність визначає, як ми керуємо собою, а саме: усвідомлення самого себе (розуміння власних емоцій та їх вплив, знання та розуміння своїх сильних та слабких сторін, розвинене почуття власної гідності, висока оцінка своїх можливостей); здатність управляти собою (самоконтроль, чесність, гідність, відповідальність, гнучкість, готовність та відкритість до нових ідей, рішень, інформації); зацікавленість (прагнення до досягнень, відданість, ініціатива, оптимізм).

Під соціальною компетентністю розуміється система складних соціальних умінь та навичок взаємодії, сценаріїв поведінки у типових соціальних ситуаціях, яка дозволяе швидко й адекватно адаптуватися, приймати рішення, ураховувати наявну ситуацію та навколишнє середовище, отримувати максимум можливого із запропонованих обставин.
Соціальна компетентність включає співчуття (повагу, розуміння інших, передбачення та задоволення їхніх потреб, створення нових можливостей); соціальні навички (комунікативні вміння, вміння керувати конфліктами, лідерство, вміння ініціювати зміни та керувати процесом змін, вміння працювати в команді).

Соціально-психологічна компетентність передбачає здатність особистості ефективно взаємодіяти $з$ людьми у системі міжособистісних відносин. Соціально-психологічна компетентність включає вміння орієнтуватися у соціальних ситуаціях, правильно визначати особистісні особливості та емоційний стан іншихлюдей, вибиратиадекватні способи спілкування й реалізувати їх у процесі взаємодії.

Під рольовою компетентністю вбачається здатність розв'язувати життєві проблеми, пов'язані з рольовою поведінкою або іiї засобами.

Комунікативна компетентність характеризується володінням складними комунікативними навичками та вміннями, формуванням адекватних умінь у нових соціальних структурах, знанням культурних норм та обмежень у спілкуванні, знання звичаїв, традицій, етикету у сфері спілкування [8].

3 огляду на вищезазначене, визначаємо, що емоційна компетентність - здатність усвідомлювати свої емоції та емоції іншої людини, здатність керувати своїми емоціями та емоціями інших людей, які дозволяють створювати доситьзначнітавимірнізміниуповедінці, стилі та продуктивності особистості. Таким чином, емоційно компетентна особистість характеризується врівноваженістю, сумлінністю, доброзичливістю, комунікабельністю, відкритістю, здатністю контролювати власні емоції, адекватно оцінюючи їх природу й причину.

У структурі емоційної компетентності особистості логічно визначити такі компоненти та рівні, як:

- афективно-когнітивний компонент (система знань про емоції, способи їх вираження, причини виникнення, розуміння власних емоційних станів і почуттів учнів, технології керування емоціями, адекватна самооцінка, емпатія, рефлексія);

- ціннісно-мотиваційний компонент (система мотивів та цінності емоцій у професійній і особистій сферах, прийняття власних емоційних переживань і почуттів, гуманістична установка на спілкування, взаємодію, мотивацію до професійної діяльності, потреби стати емоційно компетентною особистістю, досягнення успіху у професійній діяльності),

- поведінково-діяльнісний компонент (система умінь та навичок керування своїми 
емоціями, їх контролю, встановлення комунікацій, взаємодії, конструктивного впливу на емоційний стан учасників взаємодії, стимулювання їх, організації взаємодії, співпраці, попередження непорозумінь, вирішення конфліктних ситуацій).

Маркерами, що характеризують рівень розвитку емоційної компетентності, визначили високий, достатній, середній та низький рівні.

Високий рівень розвитку емоційної компетентності характеризується здатністю особистості розпізнавати власні емоції, оцінювати свій емоційний стан, визначати причини і пояснювати значення своїх емоцій, позитивно сприймати власні емоції та емоції інших людей, контролювати і регулювати свої емоції та емоції інших.

Достатній рівень розвитку емоційної компетентності характеризується здатністю розпізнавати, оцінювати, визначати причини і пояснювати значення емоцій, але не завжди позитивно сприймати емоції інших людей; спробою контролювати i регулювати свої емоції та емоції інших.

Середній рівень розвитку емоційної компетентності характеризується здатністю певним чином розпізнавати, оцінювати, визначати причини, пояснювати значення своїх емоцій та емоцій інших, але не завжди стримувати власні емоції, виявляти адекватне ставлення до оцінки власних емоцій іншими.

Низький рівень розвитку емоційної компетентності характеризується нечіткістю усвідомлення значущості емоцій у житті людини, відсутністю спроби розпізнавати, оцінювати, виявляти причини і значення своїх емоцій та емоцій інших людей.

Висновки і перспективи подальших розробок. Таким чином, емоційна компетентність розглядається як готовність і здатність людини гнучко управляти власними емоційними реакціями та реакціями інших людей, адекватно до ситуацій і умов, що змінюються, та використовувати ці здатності для досягнення важливих цілей як у житті загалом, так і у професійній діяльності зокрема.

Привабливість та різноманітність розгляду феномена емоційної компетентності полягає у тому, що управління емоціями - це навичка, яку можна сформувати й розвивати.

У контексті зазначеного важливим завданнямяктеоретичного,такіпрактичногозначення можна вважати 3'ясування функціональних конструктів розвитку емоційної компетентності особистості, що дозволить розробляти ефективні механізми розвивального впливу.

\section{Література:}

1. Андреева И.Н. Предпосылки развития эмоционального интеллекта. Вопросы психологии. Минск, 2007. № 5. C. $57-65$.

2. Бреус Ю.В. Феномен емоційного досвіду в структурі емоційного інтелекту. Науковий вісник Херсонського державного університету. Серія «Психологічні науки». Херсон, 2014. № 1. С. 127-134.

3. Власова О.І. Психологія соціальних здібностей: структура, динаміка, чинники розвитку : монографія. Київ : Видавничо-поліграфічний центр «Київський університет», 2005. 308 с.

4. Дерев'янко С. Актуалізація емоційного інтелекту в емоціогенних умовах. Соціальна психологія. Киів, 2008. № 1 (27). С. 96-104.

5. Єрмаков Т.І. Індивідуальне розуміння концепту «Я» як ключова компетентність особистості в умовах сучасного інформаційного суспільства. Наукові студї із соціальної та політичної психології. Київ : Міленіум, 2002. Вип. 6 (9). С. 200-207.

6. Зарицька В.В. Теоретико-методологічні основи розвитку емоційного інтелекту у контексті професійної підготовки : монографія. Запоріжжя : КПУ, 2010. 304 с.

7. Зимняя И.А. Ключевые компетенции как результативно-целевая основа компетентностного подхода в образовании : учебное издание. Москва : Исследовательский центр проблем качества подготовки специалистов, 2004. 40 с. Серия: Труды методологического семинара «Россия в Болонском процессе: проблемы, задачи, перспективы»».

8. Матійків I.M. Розвиток емоційної компетентності майбутніх фахівців професій типу «людиналюдина»: психологічний аспект. Проблеми та перспективи розвитку економіки $і$ підприємництва та комп'ютерних технологій в Украӥні : матеріали наук.-техн. конф. наук.-педаг. працівників. Львів, 2012. C. $240-243$.

9. Раєвська Я.М., Андрющенко К.О. Вплив емоційного інтелекту на професійну успішність працівників Державної служби зайнятості. Габітус. Вип. 25. 2021. С. 108-112. DOI: https://doi.org/10.32843/ 2663-5208.2021.25.18. URL: http://habitus.od.ua/journals/2021/25-2021/20.pdf.

10. Філіппова I. Емоційний інтелект як засіб успішної самореалізації. Вопросы психологии, 2007. № 4. C. $68-79$.

11. Bar-On R. Emotional and social intelligence: Insights from the Emotional Quotient Inventory. Handbook of emotional intelligence. San Francisco : Jossey-Bass, 2000. P. 363-388.

12. Berezka, S., Panasenko, E., Zhukova, O., Radchuk, H., Sobolyeva, S., \& Raievska, Y. Neuropsychological Peculiarities of Studying Future Psychologists' Emotional Intelligence. BRAIN. Broad Research in Artificial Intelligence and Neuroscience, 2021. No. 12(2), pp. 38-52. 
13. Gardner H. Frames of mind. New York : Basic Books, 1983.

14. Mayer J.D., P. Salovey. The intelligence of emotional intelligence. Intelligence. New York : Basic Books, 1993. Pp. 433-442.

\section{References:}

1. Andreeva, Y.N. (2007). Predposylki razvitiya emotsional'nogo intellekta [Prerequisites for the development of emotional intelligence]. Voprosy psikhologiyi, 5, 57-65. Minsk [in Russian].

2. Breus, Yu.V. (2014). Fenomen emotsiinoho dosvidu v strukturi emotsiinoho intelektu [The phenomenon of emotional experience in the structure of emotional intelligence]. Naukovyi visnyk Khersonskoho derzhavnoho universytetu, 1, 127-134. Psychological Sciences Series. Kherson [in Ukrainian].

3. Vlasova, O.I. (2005). Psykholohiia sotsialnykh zdibnostei: struktura, dynamika, chynnyky rozvytku: monohrafiia [Psychology of social abilities: structure, dynamics, factors of development]. Kyiv: Vydavnycho-polihrafichnyi tsentr "Kyivskyi universytet", 308 [in Ukrainian].

4. Derevianko, S. (2008). Aktualizatsiia emotsiinoho intelektu v emotsiohennykh umovakh [Actualization of emotional intelligence in emotional conditions]. Sotsialna psykholohiia, 1 (27), 96-104. Kyiv [in Ukrainian].

5. Iermakov, T.I. (2002). Indyvidualne rozuminnia kontseptu "Ia" yak kliuchova kompetentnist osobystosti $\mathrm{v}$ umovakh suchasnoho informatsiinoho suspilstva [Individual understanding of the concept of "I" as a key competence of the individual in today's information society]. Naukovi studii iz sotsialnoyi ta politychnoi psykholohii, 6 (9), 200-207. Kyiv: Milenium [in Ukrainian].

6. Zarytska, V.V. (2010). Teoretyko-metodolohichni osnovy rozvytku emotsiinoho intelektu u konteksti profesiinoyi pidhotovky: monohrafiia. [Theoretical and methodological foundations of the development of emotional intelligence in the context of training]. Zaporizhzhia: KPU, 304 [in Ukrainian].

7. Zimnyaya, I.A. (2004). Klyuchevye kompetentsii kak rezul'tativno-tselevaya osnova kompetentnostnogo podkhoda $\mathrm{v}$ obrazovanii: uchebnoe izdanie [Key competencies as an effective-target basis of a competence-based approach in education: educational publication]. Moscow: Research Center for the Problems of the Quality of Training of Specialists, 40 p. Series: Proceedings of the Methodological Seminar "Russia in the Bologna Process: Problems, Tasks, Prospects" [in Russian].

8. Matiikiv, I.M. (2012). Rozvytok emotsiinoi kompetentnosti maibutnikh fakhivtsiv profesii typu "liudyna-liudyna": psykholohichnyi aspekt [Development of emotional competence of future specialists of professions such as "man-man": psychological aspect]. Problemy ta perspektyvy rozvytku ekonomiky i pidpryiemnytstva ta kompiuternykh tekhnolohii v Ukraini: materialy nauk.-tekhn. konf. nauk.-pedah. pratsivnykiv, 240-243. Lviv [in Ukrainian].

9. Raievska, Ya.M., Andriushchenko, K.O. (2021). Vplyv emotsiinoho intelektu na profesiinu uspishnist pratsivnykiv Derzhavnoi sluzhby zainiatosti [The influence of emotional intelligence on the professional success of employees of the Public Employment Service]. Habitus, 25, 108-112 [in Ukrainian]. Retrieved from: http://habitus.od.ua/journals/2021/25-2021/20.pdf. DOI: https://doi.org/10.32843/2663-5208.2021.25.18.

10. Filippova, I. (2007). Emotsiinyi intelekt yak zasib uspishnoi samorealizatsii [Emotional intelligence as a means of successful self-realization]. Voprosy psykholohyy, 4, 68-79 [in Ukrainian].

11. Bar-On, R. Emotional and social intelligence: Insights from the Emotional Quotient Inventory. Handbook of emotional intelligence. San Francisco: Jossey-Bass, 2000. P. 363-388.

12. Berezka, S., Panasenko, E., Zhukova, O., Radchuk, H., Sobolyeva, S., \& Raievska, Y. (2021). Neuropsychological Peculiarities of Studying Future Psychologists' Emotional Intelligence. BRAIN. Broad Research in Artificial Intelligence and Neuroscience, 12(2), 38-52 [in English].

13. Buck, R. Motivation emotion and cognition: A developmental interactionist view. International review of studies on emotion. Chichester: Wiley, 1991. V. 1. P. 101-142 [in English].

14. Gardner, H. Frames of mind. New York: Basic Books, 1983 [in American].

15. Mayer, J.D., Salovey, P. The intelligence of emotional intelligence. Intelligence. New York: Basic Books, 1993. P. 433-442 [in English]. 